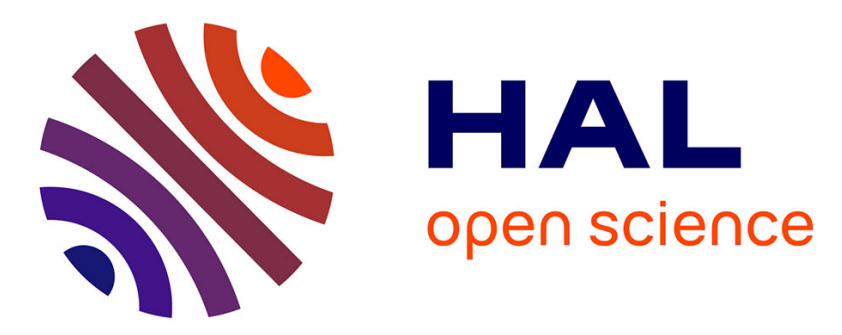

\title{
Russian energy companies and the Central and Eastern European energy sector
}

\author{
Sylvain Rossiaud, Catherine Locatelli
}

\section{To cite this version:}

Sylvain Rossiaud, Catherine Locatelli. Russian energy companies and the Central and Eastern European energy sector. Wojciech Ostrowski; Eamonn Butler. Understanding energy security in Central and Eastern Europe: Russia, transition and national interest, Routledge, pp.52-70, 2018, 9781138120341. hal-01727667

\section{HAL Id: hal-01727667 https://hal.science/hal-01727667}

Submitted on 9 Mar 2018

HAL is a multi-disciplinary open access archive for the deposit and dissemination of scientific research documents, whether they are published or not. The documents may come from teaching and research institutions in France or abroad, or from public or private research centers.
L'archive ouverte pluridisciplinaire HAL, est destinée au dépôt et à la diffusion de documents scientifiques de niveau recherche, publiés ou non, émanant des établissements d'enseignement et de recherche français ou étrangers, des laboratoires publics ou privés. 


\title{
R ussian E nergy Companies and the C entral and E astern E uropean E nergy Sector
}

\author{
Sylvain R ossiaud \\ Univ. Grenoble Alpes, C NR S, INRA, G renoble INP, GAE L, 38000 Grenoble, France \\ Sylvain.rossiaud@univ-grenoble-alpes.fr \\ Univ. Grenoble Alpes, C NR S, INRA, G renoble INP, GAE L, 38000 Grenoble, France \\ Catherine.locatelli@univ-grenoble-univ.fr
}

2016

\begin{abstract}
This contribution sets out to clarify the determinants and modalities by which Russian companies played a part in structuring the energy complex of central and eastern European countries. In so doing we seek to supplement state-centred analysis of realist inspiration. The Soviet legacy explains both the incentive for Russian companies to develop operations in downstream oil and gas in these countries and why, given the vulnerability of national energy systems, target countries tend to see such developments as a threat to their security. In this respect the mid-2000s may be seen as a turning point, with the downstream growth strategies of Russian energy suppliers increasingly called into question.
\end{abstract}

\section{JEL Q41; Q48}

\section{Introduction}

A common constraint governs the definition of policy on energy security in central and eastern European countries: their asymmetric energy interdependence with Russia means they are potentially vulnerable and exposed to the 'Russian risk' (Binhack and Tichy, 2012). For historical, economical and political reasons CEE countries are still - albeit to differing degrees - very dependent on Russian gas and oil imports. The relations established within the Comecon framework have shaped the region's oil and gas pipelines. ${ }^{1}$ Furthermore, in view of production and transport costs, Russia remains very competitive for these countries, which may in turn complicate their efforts to diversify, adopting more expensive al ternative energy sources.

Since at least the mid-2000s - and especially following the two U krainian gas crises - much of the literature on EU energy security has focused on analysis of the Russian risk and possible ways of mitigating it. Realistic analysis tends to highlight the way in which the Russian state sustains and manipulates the vulnerability of CEE and Baltic states. Russian energy policy is interpreted in the light of its use of energy as a political instrument

${ }^{1}$ The Council for M utual Economic A ssistance (Comecon) was the economic federation set up to organize trade between the planned economies of the Soviet Union and eastern and central European countries. Trade was governed by special mechanisms in terms of price formation and settlement (transferable rouble). 
(Newnham, 2011). Such analysis seeks to highlight the extent to which the route taken by a new pipeline or the price of Russian hydrocarbons reflects the Russian state's geopolitical interests in its sphere of influence. In response to EU or Nato enlargement, and informed by the Russian elite's view of a 'multipolar world' that should be structured around independent power centres, two key objectives purportedly underpin Russian energy policy (Fedorov, 2013; Braun, 2012):

i) K eeping CEE and B altic countries under control by fragmenting and isolating them from EU or $N$ ato countries. By multiplying the number of gas pipelines bypassing transit countries and/or rewarding the more compliant ones, while manipulating gas prices, this objective has been achieved (Orban, 2008).

ii) B oosting the power of the Russian state by instrumentalizing downstream investments made by national champions Gazprom and Rosneft.

According to critics of the realist current in international relations theory (Dannreuther, 2013), focusing exclusively on the interests of the Russian state can only provide a partial picture of the factors which have enabled Russian actors to structure the regional energy complex. The Russian state is not the only actor in regional energy relations. Two main reasons, in particular, explain the need to analyse the role of Russian oil and gas companies.

Firstly, at the beginning of the transition process, the rationale behind reform was to 'create' new vertically integrated actors, with international reach, capable of competing with western oil and gas companies operating abroad. The Soviet legacy explains why CEE countries were the preferred target for investment by Russian firms, notably through the purchase of shares in networks and companies (refineries, distribution companies, utilities, etc.). The prime objective of this chapter is to understand the changes which have occurred since the early 1990s in the determinants, modalities and results of Russian hydrocarbon companies' efforts to structure the CEE energy complex

Secondly, it is simplistic to assert that the behaviour of Russian oil and gas companies has only been driven by state interests. Admittedly, in view of the initial goals of reform, the behaviour of the new actors, and the coordination mechanism between them and the state, yielded some 'unexpected results'. The political, economic and institutional environment in Russia at the start of the transition process explains why it was difficult for independent firms to emerge. But the internal balance of the political economy then changed, altering the behaviour of Russian firms at home and their international development strategy. Changes also occurred abroad, in particular through the liberalization and integration of gas markets in the European Union. This institutional rupture exerted considerable influence on Gazprom's strategy in CEE countries. Our second objective is consequently to grasp the way in which internal and external changes shaped Russian companies' international growth strategy. What points of rupture are we likely to see? How do the various periods in this process explain the behaviour of Russian companies with regard to their international-growth strategies in CEE countries? Although oil and gas narratives are different we may highlight two main points, starting with the difficulties encountered normalizing relations between the companies and most CEE states. The downstream strategies of Russian companies were only limited in scale, despite the interests of Russian actors and the opportunities which arose when the various target countries started privatization (Poussenkova, 2010). M ost CEE countries sought to 
contain the expansion of Russian firms. The second point concerns the rupture observed from the mid-2000s onwards. Regarding oil, tighter state control at home - thanks to the increasingly central role played by the public company Rosneft - resulted in two key changes. On the one hand the domestic market witnessed relative normalization of the Russian companies' behaviour. On the other hand, public and private Russian companies found it increasingly difficult to penetrate the CEE downstream market. As for Gazprom, the third EU Energy Package, coupled with reforms at home and a gas bubble in the European market, forced the publicly owned company to adapt its downstream strategy in the European market.

This chapter is organized as follows. The first part presents the changes in the organizational and institutional framework of the Russian hydrocarbon industry. We present the original mode of organization resulting from reform in the early-1990s and its adjustment to suit the Russian economic and institutional environment. The second part focuses on the regional strategies of R ussian companies.

\section{E mergence of $R$ ussian oil and gas companies}

The hydrocarbon sector in Russia has seen major changes since 1991 and the collapse of the Soviet U nion, in terms of both its organization and institutional framework. This process has been different in oil and gas. Unlike the gas industry, the mass privatization programme launched at the beginning of the 1990s affected oil assets. The result now is nevertheless an organizational framework centring on powerful state-owned companies, with Gazprom in natural gas and Rosneft in oil. These two enjoy indisputable market power over the Russian market, given the scale of their production and control of infrastructure (in the first case). But they are far from being monopolies, with competitive fringes occupying substantial segments of the oil and gas markets and disputing their dominant position. This market structure came about through a process which gradually sought to bring organization models into line with the specific features of the Russian institutional and economic environment (Locatelli and Rossiaud, 2011).

\subsection{Oil R eforms Drivers}

Two key features marked reform of the oil industry during the early years of the transition process. The first one related to reorganization of oil assets. The objective was to set up vertically integrated companies reaching from exploration to downstream operations, in the place of the oil and gas ministries characteristic of the hierarchical organization enshrined in a centrally planned economy. Lukoil, Yukos and Surgutneftegas were the first vertically-integrated oil firms established on the basis of former Soviet associations (L ane and Seifulmulukov, 1999). Re-organization of the oil industry gave rise to 14 financial holdings, with either federal or regional reach ( $K$ hartukov and Starostina, 2000). In terms of the outcome private shareholders 2 held a majority share in the main companies: Lukoil (started in 1993), Surguneftegaz (1993), Y ukos (1993), Slavneft (1994), Sidanko (1994)

2 Also the following: Eastern Oil Company (1994), Onako (Orenburg Oil Company, 1994), Sibneft (1995). 
and the Tyumen Oil Company (1995). The state-owned company Rosneft and three regional companies Tatneft (1994), B achneftekhim (1995) and K omiT ek (1994) - were smaller. ${ }^{3}$

The second feature concerned the swift transfer of ownership of the new bodies to private investors. According to the instigators of reform privatization was a priority for economic and political reasons. In economic terms this meant changing the incentives for new owners in order to secure the conditions for the renewal and growth of oil and gas output through substantial productivity gains. In particular it was important to end the old extensive growth model, which maximized output to the detriment of building up reserves, despite the latter being the only guarantee of long-term hydrocarbon production in the future (Gustafson, 1989). The challenge was to use the definition of private property rights as an incentive for efficient behaviour which would guarantee long-term growth in the hydrocarbons industry. It was particularly important to refocus the attention of firms on large-scale exploration strategies, particularly in areas near Russia's 'border zones'. In political terms rapid privatization seemed necessary in order to form interest groups favourable to further reform. Keen to maximize the value of their assets the new owners would be inclined to favour reforms designed to consolidate their ownership rights and establish state regulation by contract and the rule of law. The reorganization and privatization process was supplemented by oil laws defining new modes of coordination between the state and new private-sector actors. $V$ arious formal laws were passed on regulation through competition and contracting. These measures were supplemented by the subsoil law of 1992, which defined rights of access to hydrocarbon resources through a licence-based, two-key regime jointly managed by the federal state and regional governments (Skyner, 2006; K ryukov and M oe, 1998).

\subsection{From the constitution of a private oligopoly to the emergence of a powerful state-owned oil company, Rosneft}

The Y ukos affair (2003-04) marked a break in the political economy of the Russian oil industry, with the shift from a free-market organization, rooted in the reforms initiated at the start of the transition process, towards tighter state control by means of Rosneft.

- The two privatization phases and the unexpected results of reform

Two phases need to be distinguished in the transfer of ownership of oil assets to private investors. These phases led to a separation between two types of private oil company in terms of shareholder structure. The first phase, starting at the end of 1992, corresponded to mass privatization through the issue of vouchers. The authorities adopted a fairly complicated approach. On the one hand they opened the way for corporate insiders - members of the former management - to take control. B ut at the same time the two-tier nature of privatization made it difficult for parent companies properly to control subsidiaries working on exploration and production. Under these conditions the only Soviet-oil-industry insiders to succeed in consolidating control over their subsidiaries

3 In addition to these holdings, there was a group of organizations whose status was very ambivalent, primarily Norsi Oil (started in 1995) and the Central Fuel Company (1997). They lack any real integration, simply regrouping various entities with no clear connection. 
were Vagit A lekperov (L ukoil) and V ladimir Bogdanov (Surgutneftegas). In contrast, the failure of other former Soviet managers to achieve effective integration - in particular in the case of $Y$ ukos and Sibneft - opened the way for them to be taken over by outsiders (Gustafson, 2012).

The second privatization phase (1995-97) was marked by the loans-for-shares scheme which enabled oligarchs to consolidate ownership of the leading oil companies. The scheme was based on an arrangement decided by the authorities. Russian banks made loans to the state. In exchange the latter transferred the shares in oil companies it still held to the banks as collateral, initially for a three-year period. When the state failed to pay back the loans, the banks gained permanent ownership of the assets. In this way M ikhail K hodorkovsky took control of $Y$ ukos and Roman Abramovich, Sibneft. The consolidation process which followed in the 1990s - take-over of KomiTek by Lukoil, VNK by Yukos, Slavneft by TNK, and Sibneft then Sidanko by TNK - led to the emergence of an oligopoly centring to a large extent on industrial and financial groups owned by Russian banks - Yukos, Sibneft and TNK - or by insiders - Lukoil and Surgutneftegas. By 2003 these five companies controlled $73 \%$ of Russian oil production and more than $60 \%$ of exports, whereas the weight of companies in which the state held a majority share was marginal (Locatelli, 2006).

The loans-for-shares scheme prompted much comment and criticism due to allegedly corrupt auctions and prices well below the true value of assets. It represented a break in Russia's systemic transformation, convincing public opinion at home that privatization of oil assets was illegitimate. As such it paved the way for two key factors in the political economy of Russian oil until the $Y$ ukos affair: the very short-term strategies adopted by oligarchs for managing their assets; and conflict between the centres of political and economic power, the latter brought into existence by privatization.

There is now plenty of documentary evidence that the 'transplantation' (Goldschmidt and Sweyrnert, 2006) of market institutions in Russia entailed some 'unexpected results' at a systemic level (Roland, 2000). These results mainly concern the economic forces driving reform. Contrary to what Russia had hoped, the 1990s reforms did not enable the oil industry to end the unbalanced resource management characteristic of the Soviet system, with the highest possible output and exports, and low investment in exploration. On the one hand the new actors certainly rationalized their operations and invested in brownfield sites, yielding increased production from 1999. In particular this was achieved through partnerships with oilfield service companies, enabling the modernization of production technology. On the other hand, the conditions for renewing the reserves were not guaranteed (Dienes, 2004). Despite this being its initial aim, the privatization process did not allow progress towards a pattern of growth that would secure its long-term development. A distinction must be made between $Y$ ukos, Sibneft and TNK, on the one hand, Lukoil and Surgutneftegas, on the other. Oligarchs did their utmost to maximize the short-term value of assets. The main explanation for such behaviour lay in the insecurity of private property rights (Tompson 2008; Hedlund 2001). They failed to fulfil their functional role in reducing uncertainty in an institutional context marked by the absence of the rule of law and other institutions capable of complementing and securing such rights. In contrast A lekporov and Bogdanov were less inclined to invest in modernizing and streamlining their companies. They nevertheless continued exploring new reserves (Dienes, 2004).

The observation concerning the unexpected results of reform is equally valid for the political goal behind quick privatization of assets. As an interest group the oligarchs were hostile to effective regulation by contract and the rule of law. With regard to both taxation or coordination by contract they sought to keep the law as vague as 
possible, in order to further their strategy of cash and asset stripping (Hoff and Stiglitz, 2004; Hare and M uravyev, 2002). Coordination by contract proved ineffective due to the lack of adequate enforcement capacity. The main provisions contained in the licences, thanks to which the federal state could have directed and guided the strategies of oil companies, proved inoperative. The state found itself unable to deploy effective progressive taxation based on company profits, which would have given firms an incentive to step up exploration in border zones.

Due to the ineffectiveness of formal coordination institutions, relations between the new private actors and the state were determined by a very particular hybridization of the formal market institutions with informal rules and behaviour inherited from the Soviet period. First of all, in the context of the economic crisis and demonetization which characterized the early years of the transition, the new actors resorted to barter and non-payment of debt within the framework of informal networks overlapping with those dating from the Soviet era. We then see coordination by bargaining between companies and the various political and administrative echelons. But compared with the Soviet era the focus of bargaining had shifted from negotiating production programmes and allocation of inputs to the assignment of privileges in terms of tax breaks and access to the Transneft export network (K ryukov, 2001). Lastly, as a corollary of coordination by bargaining, the federal authorities resorted to regulation by arbitrary decisions and threats. Threats focused on the withdrawal of licenses and even moves to reclaim ownership of assets. The federal authorities' failure to promote the rule of law mirrored the lack of demand on the part of the oligarchs, the Y ukos affair being the most obvious instance of this trend.

Here again we may make a distinction between the way various private companies responded to such hybrid regulation, depending on their ownership structure. In keeping with a path-dependence rationale, business leaders with a Soviet background such as Alekporov or Bogdanov were more likely than oligarchs to make allowance for the state's economic and political interests. Lukoil and Surgutneftegas thus succeeded in striking a balance in their operations between the demands of the federal authorities and a business rationale. K een to build genuinely independent firms, the oligarchs were less receptive, setting in motion a vicious circle, with all actors rejecting formal rules and companies increasingly resorting to short-term strategies.

\section{- The political economy of Russian oil after the Yukos affair}

The changes in the organization of the oil industry which started, at the latest, during V ladimir Putin's second term of office as president, were due to the difficulties the authorities had in dealing with the crisis in exploration and capturing oil rent in a free market. The shifts in the oil model undoubtedly reflect increasingly direct state control over the industry (Pleines, 2009). Primarily, the takeover of assets belonging to certain private companies - notably by way of the Y ukos affair - made possible a large state-owned conglomerate based on Rosneft.

This process has now been completed with the acquisition of all the assets of TNK -BP, making Rosneft one of the largest oil companies in the world, in terms of both production (over $4 \mathrm{~m}$ barrels a day, see Table 1) and reserves. It is also being extended through the discretionary re-allocation of exploration and production licences in favour of public companies - Rosneft, GazpromN eft and Gazprom - and through their joining consortiums previously dominated by private firms (for instance Gazprom's involvement in the development of Sakhalin-II, to the detriment of Shell). Lastly this process has been accompanied by changes in the legal and competitive framework governing the various operators' access to resources. The two-key licence system has been scrapped, 
giving full control to the federal state. Public companies enjoy preferential treatment for access to oil fields in Russia's border zones. These changes have substantially increased the relative weight of state-owned companies in oil production (see Table 1).

Table 1. M ain R ussian oil companies, by level of production in million barrels a day

\begin{tabular}{|l|l|l|l|l|}
\hline & Oil companies & $\mathbf{2 0 0 9}$ & $\mathbf{2 0 1 1}$ & $\mathbf{2 0 1 4}$ \\
\hline \multirow{4}{*}{ Private companies } & Lukoil & 1.80 & 1.73 & 1.99 \\
\cline { 2 - 5 } & TNK -B P & 1.41 & 1.44 & - \\
\cline { 2 - 5 } & Surgutneftegaz private, 50\% & 1.18 & 1.22 & 1.2 \\
\cline { 2 - 5 } & $\begin{array}{l}\text { Slavneft (50\% } \\
\text { public) }\end{array}$ & 0.31 & 0.36 & 0.33 \\
\cline { 2 - 5 } & RussN eft & & & \\
\hline $\begin{array}{l}\text { State-owned } \\
\text { companies }\end{array}$ & Rosneft & 0.24 & 0.26 & $0.15(2012)$ \\
\cline { 2 - 5 } $\begin{array}{l}\text { Regional } \\
\text { companies }\end{array}$ & Gazprom Neft & 2.41 & 2.28 & 4.16 \\
\hline Tashneft & 0.59 & 0.6 & $1.05(1)$ \\
\cline { 2 - 5 } Tatneft (1) & & 0.25 & 0.3 & 0.4 \\
\hline
\end{tabular}

Note: (1) To obtain total production, add $0.17 \mathrm{mB} / \mathrm{D}$, representing GazpromN eft's share in Slavneft, to $0.12 \mathrm{mB} / \mathrm{D}$, representing GazpromN eft's share in Tomskneft V NK .

Over and above the change in the structure of ownership rights, in what respect does this reform represent a rupture in the political economy of Russian oil at home? First of all this reform undoubtedly reflects a change in the balance of power in Russia's elite, marked by the growing influence of the siloviki, in particular Igor Sechin. It would nevertheless be a mistake to reduce the Yukos affair to just a shift in the balance of power at home. Advocates of a free market also supported consolidation of Rosneft. Furthermore, greater state-control has brought on a period of increasingly effective coordination by contract. The authorities are using Rosneft as a benchmark, thus enhancing information-sharing with operators. The Russian authorities have started a learning process, curtailing the conflict-ridden, discretionary re-negotiations of the 1990s. They have altered the beliefs of private companies concerning the credible commitment of the state, prompting them to change their approach to exploration accordingly. Indeed the third change in the behaviour of Russian companies concerns their management of reserves. Actors, both public and private, and international companies are now engaged in exploration work (Henderson, 2011), emblematic of the relative normalization of their behaviour compared to their international peers.

\subsection{G azprom, the dominant company in the $\mathrm{R}$ ussian gas market}

In terms of its organization the gas industry took an altogether different course from its petroleum-based counterpart. The production associations making up the Soviet gas ministry were brought together to form Gazprom, a vertically integrated company with the state as its initially dominant (38\%) and ultimately majority shareholder, from the 2000s onwards. At the beginning of the century a raft of liberal reforms based on the European model, involving de-integration and more competition, was debated then shelved. However, in recent years an original type of reform has been framed, in an effort to normalize Gazprom's behaviour by subjecting it to competition at home. 


\section{- Debate on reform of the gas industry}

At the start of the transition process re-organization of the industry gas prompted lively debate in Russia. Up to 1993 two competing approaches were advocated. One sought to maintain a centralized, integrated gas industry. B roadly supported by Gazprom management, this approach was in stark contrast with the liberal stance backed by reformers, determined to end the state gas concern's monopoly over production. M any members of the government led by $\mathrm{Y}$ egor $\mathrm{G}$ aidar supported re-organization along these lines. Taking his cue from reform of the oil industry, energy minister V ladimir Lopukhin sought to split Gazprom into several parts. The appointment of Viktor Chernomyrdin as prime minister confirmed consolidation of Gazprom. Chernomyrdin, who had headed the Soviet gas industry ministry and handled the setting up of Gazprom, was firmly opposed to breaking up the monopoly (K hripunov and M atthews, 1996).

In the early 2000s the new minister of economic development German Gref tabled a liberal reform programme involving de-integration and tougher competition (A hrend and Tompson, 2004). Restructuring projects centred on vertical de-integration of Gazprom, the aim being to separate production and transport functions (in keeping with a patrimonial-unbundling rationale) in order to isolate competitive segments from those enjoying a natural monopoly. From a competitive point of view the aim was also to set up six production companies based on those wholly owned by Gazprom. Though reduced to its role as a transporter, operating as a natural monopoly under state ownership and subject to regulation allowing third-party access to the network, Gazprom would nevertheless have retained its position as the only gas exporter, this being the sole concession to the European model. In a final stage (2007-13), G azprom would have limited itself to just its export business (L ocatelli, 2003). Nevertheless the feasibility and credibility of this reform based on the EU's de-integrated, competitive model was impeded by the accumulation of substantial non-payments and low gas prices. These two mechanisms led to regulation by quantities, disregarding any concern for profit or costs. The company enjoyed preferential access to the rent from exports to the European market, enabling it to fund investment. In exchange it was required to fulfil the long-term, take-or-pay contracts passed with European countries.

- Independent firms dispute G azprom's market power

The structural changes in the Russian market are now casting doubt on this model. There is no question of vertically de-integrating Gazprom, but the state wants to subject the company to competition, in particular in order to impose norms on its behaviour (Locatelli, 2014). Independent firms - private gas companies and oil companies with reserves they wish to monetize - have thus become key players in the Russian market. However they lack access to the international market (except Rosneft and Novatek which export liquefied natural gas to A sia).

Table 2. R ussian gas production by producer

\begin{tabular}{|l|l|l|l|l|l|l|l|l|l|l|}
\hline $\mathbf{G ~ m}^{\mathbf{3}}$ & $\mathbf{1 9 9 6}$ & $\mathbf{2 0 0 6}$ & $\mathbf{2 0 0 7}$ & $\mathbf{2 0 0 8}$ & $\mathbf{2 0 0 9}$ & $\mathbf{2 0 1 0}$ & $\mathbf{2 0 1 1}$ & $\mathbf{2 0 1 2}$ & $\mathbf{2 0 1 3}$ & $\mathbf{2 0 1 4}$ \\
\hline G azprom & 564.7 & 556.0 & 548.6 & 549.7 & 462.2 & 506.6 & 509.8 & 479 & 480 & 445 \\
\hline Others & 38.3 & 100.2 & 104.1 & 113.9 & 120.2 & 141.7 & 160.7 & 176 & 188 & 134 \\
\hline Total & 603 & 656.2 & 652.7 & 663.6 & 582.4 & 650.3 & 670.5 & 655 & 668 & 579 \\
\hline
\end{tabular}

Sources: Gazprom; Russian Energy M inistry 
Significant increases in regulated prices have opened the way for greater competition in the Russian gas market. ${ }^{4}$ Between 2006 and 2010 these prices increased by 124\% for industrial customers, 121\% for residential consumers. This rise has gradually done away with the price differentials between the regulated market supplied by Gazprom and the 'free' market mainly supplied by independent firms and oil companies (and in a marginal way by Gazprom itself, particularly in the case of its 'new gas'), enabling competition in the industrial and electrical sectors at least, between Gazprom and other gas operators. In some niches of the gas market the latter can now compete on equal terms with Gazprom (Henderson, 2013). This change is gradually allowing a more competitive gas market to take shape, no longer managed exclusively with a view to rationing, but increasingly with a market rationale. Competition between Gazprom and the other gas operators has also come about through stricter control over access to Gazprom's transport network. It should be borne in mind that the gas-pipeline network is a natural monopoly, so rules on third-party access are a necessary pre-condition for introducing competition to this market. Third-party access organizes free access to the transport network on equal terms for all producers. This system has existed in Russia since 1997, but initially it was rarely enforced or subject to the whims of Gazprom, it being the only one to hold information on the rate of use of transport capacity. It seems that this situation is now changing ( $Y$ afimava, 2015).

\section{The strategies of R ussian energy companies in central and eastern E urope}

The largest R ussian companies have persistently asserted themselves as 'real' energy companies in international hydrocarbon markets. Limited at home by institutional and economic conditions specific to the Russian transition, they have looked abroad to derive the greatest benefit from exports and maximize the associated rent. To this end they have sought to deploy international growth strategies, the better to maintain and secure their export sales. As former members of the eastern bloc, CEE countries represented the prime target for experimenting such policies. However, the results were fairly uneven. We shall start by reviewing the forces driving international development of Russian oil companies in central and eastern Europe, and the corresponding results. Then we shall look in greater detail at Gazprom's downstream strategy, subsequently thrown into doubt by EU rules on energy markets and - more broadly - by issues of energy security. The latter have proved a determining factor in relations between Gazprom and CEE countries with regard to gas.

\subsection{International growth strategy of R ussian oil companies in central and eastern E urope}

In the 1990s the international development strategies of R ussian oil companies diverged. Surgutneftegas, Sibneft and TNK -B P concentrated on the home market, whereas Lukoil and, to a lesser extent, Y ukos developed abroad.

\footnotetext{
${ }^{4} \mathrm{~N}$ ew gas operators have thus gradually emerged in the unusual context of parallel markets, one with regulated prices, the other not (A hrend, and Tompson, 2004). One supplies gas to households at regulated prices, Gazprom being its sole supplier. Industry (in particular electricity) also uses this market, but on the basis of quotas negotiated with Gazprom. Over and above these negotiated quantities, supplied at regulated prices, consumers may resort to a 'free' market, with unregulated prices.
} 
In particular this led to investment in downstream oil in CEE countries (taking shares in refining industries and filling stations, for example). ${ }^{5}$ Lukoil was fairly successful in this respect, as can be seen from Table 3.

Two economic rationales presided over such investments. Firstly direct access to foreign markets was a priority, given the low price of petroleum products at home and the problem of non-payment. Secondly the acquisition of refineries enabled Lukoil and Y ukos to delay CEE countries' attempts to diversify sources of supply and thus set prices that reflected their market power. It is essential in this respect to bear in mind the legacy of economic and technological interdependence left over from the days of Comecon (Balmaceda, 2013). At the start of the transition process, in addition to the concentration of oil imports from Russia, this interdependence resulted in two types of vulnerability in the oil supply chains of CEE countries. Relations between the USSR and satellite countries organized crude-oil supply systems. The D ruzhba pipeline, for instance, still carries an essential part of the oil supply to this region. Furthermore local refineries were only viable if they processed large volumes of Russian crude oil. The interdependence left over from the Soviet era therefore explains why it made economic sense for Russian companies to take control of these facilities. At the same time such moves represented a significant threat to target countries. Petr Binhack and Lukas Tichy (2012) point out that Lukoil's investments in downstream oil in the Czech Republic could only be a source of concern for its authorities. This move could have led to a Russian firm gaining control of the only refinery equipped to process crude oil from sources other than Russia.

$M$ any countries consequently saw Lukoil's investments in downstream oil as a threat to their energy security. Two additional factors drove this process. The first related to the fact that Lukoil was seen as an instrument of Russian foreign policy. As already stressed, Alekporov was always sympathetic to state interests, at home and abroad. The second factor was the vulnerability of CEE countries, which could be instrumentalized to promote investments by Russian companies. The most symptomatic example was Transneft's repeated stoppage of supplies during privatization of Mazeikiu $\mathrm{Nafta}$ in Lithuania, apparently to favour its takeover by $\mathrm{Y}$ ukos (Duncan, 2007).

In the 2000s efforts to secure supply severely limited Russian investments. In 2002 Lukoil failed in its attempt to buy the $\mathrm{G}$ dansk refinery in Poland. It also failed to buy a stake in the Lithuanian refinery Mazeikiu Nafta in 2005. These two examples are emblematic of the difficult normalization of relations between Russian companies and some CEE states (Pleines, 2006). Furthermore, with the fall in oil prices, Lukoil has announced plans to reorganize its downstream business, which may lead to it disengaging from large parts of its activities in Baltic states, Czechia, Slovakia, Hungary and U kraine (Corcoran, 2016).

Table 3 highlights the absence of Rosneft from the CEE downstream market. The international strategy of Rosneft is more focused on upstream oil. Following the principle of reciprocity known as 'assets for assets' (B elyi 2009), Rosneft has used its partnership with international oil companies in Russia to expand its upstream operations globally. A fter its failure to buy a $25 \%$ share in the Croatian state oil company INA (Poussenkova 2010), its main investment in downstream oil in the EU was the acquisition of a 50\% stake in Germany's Ruhr Oel's joint venture (Henderson 2012).

5 To diversify production and reserves geographically Lukoil led the way among Russian companies towards international development, by means of investments in exploration and production. CEE countries, with their limited petroleum resources, were concerned by such expansion. 
Table 3. R ussian oil companies' main investments in CEE and Baltic countries

\begin{tabular}{|c|c|c|c|c|c|c|}
\hline & Company & $\begin{array}{l}\text { Filling } \\
\text { stations }\end{array}$ & $\begin{array}{l}\text { Oil } \\
\text { exploration } \\
\text { and } \\
\text { production }\end{array}$ & Oil pipeline & $\begin{array}{c}\text { Oil } \\
\text { refinery }\end{array}$ & $\begin{array}{l}\text { Russian } \\
\text { company }\end{array}$ \\
\hline Bulgaria & $\begin{array}{l}\text { Neftohim } \\
\text { B urgas }\end{array}$ & $x$ & & & $x$ & Lukoil \\
\hline Czechia & $\begin{array}{l}\text { Conoco Petrol } \\
\text { Stations (1) }\end{array}$ & $x$ & & & & Lukoil \\
\hline E stonia & $\begin{array}{l}\text { Lukoil-E urodek } \\
\text { (2) }\end{array}$ & $x$ & & & & Lukoil \\
\hline Lithuania & $\begin{array}{c}\text { M azeikiu N afta } \\
\text { (3) }\end{array}$ & & & & $x$ & Yukos \\
\hline Hungary & MOL (4) & & & $\begin{array}{c}\mathrm{x} \text { (gas } \\
\text { transmission } \\
\text { system) } \\
\end{array}$ & $x$ & $\begin{array}{c}\text { Surgutneftegas } \\
(2009)\end{array}$ \\
\hline Poland & $\begin{array}{c}\text { Conoco Petrol } \\
\text { Stations }\end{array}$ & $x$ & & & & Lukoil \\
\hline Romania & Petrotel L ukoil & $x$ & & & $x$ & Lukoil \\
\hline Slovakia & & & & & & Lukoil \\
\hline & Transpetrol (5) & & & $x$ & & Yukos \\
\hline Slovenia & & $\mathrm{X}$ & & & $x$ & Lukoil \\
\hline
\end{tabular}

Sources: Goldman (2008); Henderson and Radisevic (2003).

Notes:

(1) In 2014 Lukoil sold all its filling station in Czechia, mainly to M OL.

(2) Oil product terminal

(3) Now owned by the Polish company Orlen

(4) In 2011 the Hungarian government repurchased the $21.1 \%$ stake from Surgutneftegas.

(5) In 2009 the Slovak government repurchased the $49 \%$ stake from Y ukos, which had filed for bankruptcy.

\subsection{The specific issue of natural gas: energy security at stake}

CEE countries are more exposed to the 'Russian risk' with regard to gas than oil, the latter being a genuinely international market. Given the nature of the gas industry - network industry, relative weight of transmission costs in the overall price, two-way dependence between producer and consumer-countries induced by the specific nature of assets - the interdependence developed during the Soviet era is still subject to considerable inertia. Some countries remain very dependent on Russian gas because of the route taken by gas pipelines built during the Soviet era. CEE countries still import large amounts of natural gas from Russia. The rate of dependence on Russian gas varies from $100 \%$ in Bulgaria to $50 \%$ in Czechia (see Table 4). Furthermore economic factors also contribute to sustaining high levels of dependence on Russian imports. Due to the proximity of these markets, relatively low production and transport costs, Russian gas is extremely competitive for these countries. This is particularly true of Poland, Czechia and Slovakia, all three major transit countries for Russian gas on its way to W estern Europe. 
Table 4. Dependence of CE E countries on R ussian gas, 2014

\begin{tabular}{|l|c|c|l|}
\hline Country & Volume $\left(\mathrm{Gm}^{3}\right)$ & $\begin{array}{l}\text { Russian imports/ total } \\
\text { imports (\%) }\end{array}$ & $\begin{array}{l}\text { Russian imports } \\
\text { /consumption (\%) }\end{array}$ \\
\hline Bulgaria & 2.8 & 100 & 100 \\
\hline E stonia & 0.4 & 100 & 100 \\
\hline Latvia & 1.0 & 100 & 100 \\
\hline Lithuania & 2.5 & 100 & 100 \\
\hline Hungary & 5.4 & 64.3 & 64.3 \\
\hline Poland & 9.1 & 55.8 & 55.8 \\
\hline Czechia & 8.0 & 75.2 & \\
\hline Slovakia & 4.4 & 100 & 100 \\
\hline
\end{tabular}

Sources: Gazprom, 2015 annual report; B P Energy statistical review, 2015.

Gazprom has adopted two strategies in the region. The first one is the expression of price-based market power. Gazprom derives an essential share of its profits from exports and one may assume that its prime aim is to maximize gas rent, and consequently its profits in Europe. Accordingly, in non-competitive environments, the firm seeks to impose what may be seen as 'unfair prices'. Such strategies are part and parcel of behaviour which J onathan Stern (2014) qualifies as a 'profit-maximizing monopolist'. This is wholly consistent with the goals of the Russian state which is determined to maximize fiscal revenue from hydrocarbons in order to balance its budget.

The second strategy deployed by Gazprom may be construed as a 'response' to liberalization of EU gas markets and the creation of a competitive environment, organized by the 1996 and 1998 directives and the third EU Energy Package of 2009. Gazprom is trying to move further downstream in the European market, in order to guard against the price and volume risks brought about by EU liberalization. To secure, enlarge and perhaps better capitalize on its exports, a natural-gas supplier may be tempted by greater downstream involvement, reaching at least as far as wholesale trade. This strategy, which involves acquiring assets in transport, storage and distribution companies, or even large gas consumers (typically electricity utilities), enables a producer to sell their product without passing through competitive wholesale markets (Eikeland, 2007) and in many case thus obtain greater profit. Downstream integration is a way of recovering the margin of intermediate operators on various downstream segments. In central and eastern Europe this strategy has focused in particular on purchasing large shares in long-distance transport networks, primarily leading to Europe (the best example is Gazprom's share in the EuroPolGaz which is operating the $Y$ amal pipeline to Europe; see Table 5). Through this type of investment $\mathrm{G}$ azprom also hopes to secure and control its supply lines to W estern Europe, even if the construction of Nord Stream has made this approach less important. 
Table 5: Gazprom's main investments in CEE and in the Baltic states

\begin{tabular}{|c|c|c|c|c|}
\hline Country & Date & J oint-venture & $\begin{array}{l}\text { Gazprom } \\
\text { share (\%) }\end{array}$ & Nature of joint venture \\
\hline Bulgaria & & Overgas & 50 & $\begin{array}{l}\text { Natural gas transport services, } \\
\text { marketing }\end{array}$ \\
\hline Estonia & 1992 & Eesti Gaas & 37.5 & $\begin{array}{l}\text { Transport and distribution } \\
\text { In J anuary } 2014 \text { E esti Gaas sold off } \\
\text { a gas grid operator, } \\
\text { EG V orguteenus. V orguteenus } \\
\text { Valdus purchased the whole firm. } \\
\text { Gazprom subsequently took } \\
\text { a } 37.03 \% \text { stake in Vorguteenus } \\
\text { Valdus, while retaining a } 37.03 \% \\
\text { share in Eesti Gaas. }\end{array}$ \\
\hline \multirow[t]{3}{*}{ Hungary } & 1994 & Panrusgaz (M ol) & 40 & $M$ arketing and distribution \\
\hline & 2006 & & & $\begin{array}{l}\text { Share in E.ON Foldag Storage and } \\
\text { E.ON Foldaz, and in regional gas and } \\
\text { electricity suppliers under the terms } \\
\text { of an agreement with E.ON } \\
\text { concerning its assets in M ol } \\
\text { E.ON has concluded an agreement to } \\
\text { sell its } 100 \% \text { stake in E.ON Földgáz } \\
\text { Trade and E.ON Földgáz Storage to } \\
\text { M VM Hungarian Electricity. }\end{array}$ \\
\hline & & Borsodchem & 25 & Petrochemical production \\
\hline Latvia & 1997 & Latvijas Gaze & 34 & M arketing and distribution \\
\hline \multirow[t]{2}{*}{ Lithuania } & & Stella Vitae & 30 & M arketing and distribution \\
\hline & & $\begin{array}{l}\text { Lietuvos Dujos } \\
\text { A mber Grid (2013) }\end{array}$ & $\begin{array}{l}37.1 \\
37.1\end{array}$ & Transport, marketing and distribution \\
\hline \multirow[t]{2}{*}{ Poland } & 1993 & $\begin{array}{l}\text { EuroPolGaz } \\
\text { (PGNiG) }\end{array}$ & 48 & $\begin{array}{l}\text { Transport (gas pipeline; Y } \\
\text { Europe) }\end{array}$ \\
\hline & & $\begin{array}{ll}\text { Gaz } & \text { Trading } \\
\text { (PGNiG) } & \end{array}$ & 16 & M arketing and trading, gas and LNG \\
\hline \multirow[t]{2}{*}{ C zechia } & & Gas-Invest & 37.5 & M arketing, distribution and trading \\
\hline & & Vemex & 33 & Trading \\
\hline Slovakia & & Slovrusgaz (E.ON) & 50 & Transport and marketing \\
\hline
\end{tabular}

\section{- Questioning Gazprom strategy}

Gazprom's efforts to move further downstream have been hindered by the interests and energy policies of CEE countries. On the grounds of energy security the latter have sought to restrict investments by the Russian gas company. ${ }^{6}$ The determining factors in this process, previously discussed with regard to investments in the oil supply chain, play an even more important part in the case of gas. For many states, moves by Gazprom to take control of gas networks or distribution companies can only increase and sustain the vulnerability of their national

${ }^{6} \mathrm{~A}$ clear instance of this trend was the refusal, in the $2000 \mathrm{~s}$, by the Romanian state to allow Gazprom to take a stake in its two gas distribution companies Distrigaz Sud and Distrigaz Nord when they were privatized. Instead its preference went to GDF and E.ON. 
gas system. Such moves would enable Gazprom to raise barriers blocking market-entry, thus limiting diversification policies in these countries while enabling the Russian company to fix prices in line with its market power (Smith, 2004). ${ }^{7}$ We should nevertheless point out that many countries have sought to diversify their sources of gas supply, either by finding new suppliers (LNG, Norway, etc.) or by developing shale gas (as in Poland, for instance). It now seems that divergent energy policies are taking shape in the region, hinging in particular on how large a part Russia plays in the gas supply. Some countries, such as Bulgaria and Hungary, are keen to obtain a cheaper supply and have consequently sought closer ties with Russia, witness their determination to continue the South Stream project despite EU opposition. ${ }^{8}$

The other factor underpinning the concern regarding Gazprom's downstream investments relates to the close links between the political and economic determinants of its pricing strategy. Although it is a central issue, it is difficult to reach any definite conclusion on the relative weight of these two determinants. According to Stern the data on long-term contracts signed by Gazprom reflects its determination to set prices corresponding to its market power in all importing countries. In contrast U kraine and Belarus show that it may also use gas prices as a political weapon in the service of Russian foreign policy.

However it seems to be increasingly difficult to use gas prices for political ends - made possible by Gazprom's market power - in the EU. The Community's free-market policies, designed to bring Gazprom's behaviour into line with prevailing norms by promoting competition, diversifying supply and integrating national markets in a single whole, are beginning to bear fruit (Goldthau and Sitter, 2015). Competition policy seeks to limit the market power of $\mathrm{G}$ azprom by allowing the development of a competitive fringe. In this respect, the construction of LNG terminals - $3 \mathrm{Gm}^{3}$ in Lithuania - as well as better interconnection between eastern and western Europe via Germany, increase the threat of new entrants in some of the region's markets. ${ }^{9}$ These developments have forced Gazprom to accept re-negotiation of certain contracts while tending to decrease the price differential between countries. Russia's withdrawal from the provisional application of the Energy Charter Treaty announced in 2009 ended EU attempts to export the community energy acquis to Russia and in so doing create a common energy market integrating the EU's suppliers (Cameron, 2010; K eating, 2012). EU competition policy nevertheless impacts on the behaviour of G azprom in the EU market, gradually reducing its market power.

Furthermore the third EU Energy Package, in particular the rules on unbundling ${ }^{10}$ and the Third-Country reciprocity clause have made life extremely difficult for Gazprom's industrial and international-growth strategies, above all due to the impact of these measures on attempts to adapt through downstream integration.

7 The inquiry launched by the European Commission focuses on 'abuse of [Gazprom's] dominant market position in breach of EU antitrust rules'. A part from the matter of prices, the inquiry carried out by the DG for Competition concerns strategies which may seek to partition markets and prevent diversification of gas supplies. It covers the Baltic countries, Poland, Hungary and Bulgaria. According to the Commission the contracts Gazprom has signed with companies in these countries contain territorial restrictions forbidding exports, destination clauses which hinder competition and are contrary to EU rules. It has also been alleged that Gazprom negotiated deliveries in exchange for commitments on transport infrastructure. European Commission press release of 22 A pril 2015.

8 The agreements with these countries did not comply with prevailing EU rules on gas pipeline networks.

${ }^{9}$ See 'Eastern Europe: Russian gas price ceilings'. Energy Economist, n 406, A ugust 2015, pp. 7-16.

10 Unbundling involves separating, in legal or accounting terms, the various segments of the gas supply chain, to prevent vertical integration, seen as a barrier to new operators. 
The rules on unbundling make it impossible for a producer and supplier such as Russia also to act as a transmission system operator in an EU Member State (Willems et al, 2010). In addition the Third-Country reciprocity clause, also known as the 'anti-Gazprom clause', opens the way for discriminatory treatment of foreign investments. Companies held by shareholders located outside the EU must demonstrate that they will not jeopardize EU energy security, before they can operate in the Union. Russia sees these two rules as a real barrier to its investments in the EU energy sector. Renegotiation of the gas-transit contract between Poland and Russia is a good illustration of the implications of this rule. Until now EurRoPol Gaz, a joint-venture between Poland's PGNiG and Gazprom, managed the part of the $Y$ amal gas pipeline located in Poland. Henceforth it will be in the hands of the Polish operator Gaz-System. ${ }^{11}$

\section{Conclusion}

This contribution sets out to clarify the determinants and modalities by which Russian companies played a part in structuring the energy complex of central and eastern European countries. In so doing we have sought to supplement state-centred analysis of realist inspiration. The Soviet legacy explains both the incentive for R ussian companies to develop operations in downstream oil and gas in these countries and why, given the vulnerability of national energy systems, target countries tend to see such developments as a threat to their security. In this respect the mid-2000s may be seen as a turning point, with the downstream growth strategies of Russian energy suppliers increasingly called into question. Lukoil, for instance, is now disengaging from several CEE countries. As for Gazprom, the economic and institutional changes in the EU market have significantly complicated its downstream growth and its use of strategic pricing.

\section{References}

A hrend, R. and Tompson, W. (2004) Russia's Gas Sector: The Endless Wait for Reform?, Economics Department Working Paper, $n^{\circ} 402$ (Paris, OECD).

Belyi, A. (2009) 'Reciprocity as a Factor of the Energy Investment Regimes in the EU-Russian Energy Relations', J ournal of World Energy Law \& Business, 2, 2, pp. 117-128.

Balmaceda, M.M. (2013) The Politics of Energy Dependency. Ukraine, Belarus, and Lithuania between D omestic Oligarchs and Russian Pressure (Toronto, University of Toronto Press).

B inhack, P. and Tichy, L. (2012) 'A symmetric Interdependence in the Czech-Russian Energy Relations', Energy Policy, 45, pp. 54-63.

B raun, A. (2012) 'Resetting Russian-Eastern European Relations for the $21^{\text {st }}$ Century', Communist and PostCommunist Studies, 45, pp. 349-400.

Cameron, F. (2010) 'The Politics of EU-Russia Energy Relations', in Talus K. \& Fratini P. (eds.) EU-Russia Energy Relations (B russels, Euroconfidential), pp. 25-38.

Corcoran, J. (2016) 'Currency Crash Hits Russia's Foreign A ssets', Petroleum Economist, M arch 2016, pp. 4243.

11 The latter pledged to allow TPA operation for the pipeline's unreserved capacity (Poland and Russia reach compromise deal with EU on long term gas supply and transit, Gas M atters, Dec-J an 2011). 
Dannreuther, R. (2013) International Security. The Contemporary Agenda, Second Edition (Cambridge, Polity Press).

Dienes, L. (2004) 'Observations on the Problematic Potential of Russian Oil and the Complexities of Siberia', Eurasian Geography and Economics, 45, 5, pp. 319-345.

Duncan, P. (2007) 'Oligarchs', Business and Russian Foreign Policy, Economic Working Paper 83 (London, Centre for the Study of E conomic and Social Change in Europe).

Eikeland, 0. (2007) 'Downstream natural gas in Europe - High hopes dashed for upstream oil and gas companies', Energy Policy, 35, 1, pp. 227-237.

Fedorov, Y . (2013) 'Continuity and Change in Russia's Policy toward Central and Eastern Europe', Communist and Post-Communist Studies, 46, pp. 315-326.

Goldman, M. (2008) Petrostate. Putin, Power and the New Russia (Oxford, Oxford University Press).

Goldschmidt, N. and Zweyrnert, J. (2006) 'The Two Transitions in Central and Eastern Europe as Processes of Institutional Transplantation', J ournal of E conomic Issues, XL, 4, pp. 895-918.

Goldthau, A. and Sitter, N. (2015) A Liberal Actor in a Realist World. The European Union Regulatory State and the Global Political E conomy of Energy (Oxford, Oxford U niversity Press).

Gustafson, T. (1989) Crisis amid Plenty. The Politics of Soviet Energy under Brezhnev and Gorbachev (Princeton, Princeton U niversity Press).

Gustafson, T. (2012) Wheel of F ortune. The Battle for Oil and Power in Russia (London, The Belknap Press of Harvard U niversity Press).

Hare, P. and M uravyev, A . (2002) Privatization in Russia, Research Paper Series, (Russian-E uropean Centre for Economic Policy).

Hedlund, S. (2001) 'Property without Rights: Dimensions of Russian Privatisation', Europe-Asia Studies, 53, 2, pp. 213-237.

Henderson, J. (2013) Competition for Constumers in the Evolving Russian Gas Market. NG 73, Oxford Institute for Energy Studies.

Henderson, J. (2012) Rosneft - On the Road to Global NOC Status?, Working paper 44, (Oxford, Oxford Institute for Energy Studies).

Henderson, J. (2011) The Strategic Implications of Russia's Eastern Oil Resources, W orking paper 41, (Oxford, Oxford Institute for Energy Studies).

Henderson, J. and Radosevic, S. (2003) The Influence of Alliances on Corporate Growth in the Post-Soviet Period: Lukoil and Yukos, Working Paper 34, (London, Centre for the Study of Economic and Social Change in Europe).

Hoff, K. and Stiglitz, J.E. (2004) 'A fter the Big Bang? Obstacles to the Emergence of the Rule of Law in PostCommunist Societies', American Economic Review, 94, 3, pp. 753-763.

Keating M.F. (2012) 'Re-Thinking EU Energy Security: The Utility of Global Best Practices for Successful Transnational Energy Governance' in Kuzemko C., B elyi A. V., Glodthau A. and Keating M. F. (eds.) Dynamics of Energy Governance in Europe and Russia (Basingstoke and New York, Palgrave M acmillan), pp. 86-105.

K hartukov, E. and Starostina, E. (2000) 'Russia's Oil Privatization is M ore Greed than Fear', 0il \& Gas J ournal, 98,27, pp. 30-32.

K hripunov, I. and M atthews, M .M . (1996) 'Russia's Oil and Gas Interest Group and Its Foreign Policy A genda', Problems of P ost-Communism, 43, 3, pp. 38-48.

Kryukov, V. and Moe, A. (1998) 'Joint Management of Oil and Gas Resources in Russia', Post-Soviet Geography and Economics, 39, 7, pp. 588-605.

Lane, D. and Seifulmulukov, I. (1999) 'Structure and Ownership' in Lane D. (ed.) The Political Economy of Russian Oil (Lanham, Rowman \& Littlefield), pp.15-45.

Locatelli, C. (2014) 'The Russian gas industry: challenges to the 'Gazprom model'?', Post Communist Economies, 26, 1, pp. 53-66.

Locatelli, C. and Rossiaud, S. (2011) 'A Neo Institutionalist Interpretation of the Changes in the Russian Oil Model', Energy Policy, 39, 9, pp. 5588-5597.

Locatelli, C. (2006) 'The Russian Oil Industry between Public and Private Governance: Obstacles to International Oil Companies' Investment Strategies', Energy Policy, 34, 9, pp. 1075-1085. 
Locatelli, C. (2003) 'The Viability of Deregulation in the Russian Gas Industry', J ournal of Energy and Development, 28, 2, pp. 221-238.

Newnham, R. (2011) 'Oil, Carrots, and Sticks: Russia's Energy Resources as a Foreign Policy Tool', J ournal of Eurasian Studies, 2, pp. 134-143.

Orban, A. (2008) Power, Energy, and the New Russian Imperialism (W estport, Preager Security International).

Pleines, H. (2009) 'D eveloping Russia's Oil and Gas Industry. What Role for the State?' in Perovic J., Orttung R. \& Wenger A. (eds) Russian Energy Power and Foreign Relations. Implications for Conflict and Cooperation (London, Routledge), pp. 71-86.

Pleines, H. (2006) 'Russian Energy Companies in the Enlarged European Union' in W enger A., Perovic J. \& Orttung R. (eds) Russian Business Power. The Role of Russian Business in F oreign and Security Relations (London, Routledge), pp. 47-66.

Poussenkova, N. (2010) 'The Global Expansion of Russia's Energy Giant', J ournal of International Affairs, Spring/Summer, 63, 2, pp. 103-124.

Roland, G. (2000) Transition and Economics: Politics, M arkets and Firms (Cambridge, M IT Press).

Smith K. C. (2004) Russian Energy Politics in the Baltics, Poland, and U kraine. A New Stealth Imperialism?, (W ashington D.C, Centre for Strategic and International Studies).

Skyner, L. (2006) 'The Regulation of Subsoil Resource U sage: the Erosion of the "Two key" Principle and Its Inclusion into the Framework of Civil Law', Review of Central and East European Law, 2, 4, pp. 127-157.

Stern, J. (2014) 'The impact of European Regulation and Policy on Russian Gas Exports and Pipelines' in Henderson J. \& Pirani S. (eds.) The Russian Gas M atrix: How Markets are Driving Change (Oxford, The Oxford University Press).

Tompson, W. (2008) Back to the Future? Thoughts on the Political Economy of Expanding State Ownership in Russia, Les Cahiers Russie ${ }^{\circ} 6$, (Paris, CERI).

Willems, A., Sul, J. and Benizri, Y. (2010) 'Unbundling as a Defence M echanism against Russia: Is the EU Missing the Point?' in Talus, K. \& Fratini P. (eds.) EU-Russia Energy Relations (Brussels, Euroconfidential), pp. 227-244.

Y afimava, K . (2015). Evolution of gas pipeline regulation in Russia: Third party access, capacity allocation and

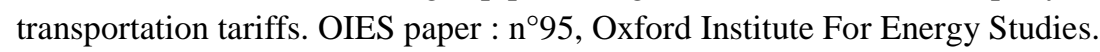

